\title{
Formulation and Evaluation of Roflumilast Fast dissolving Tablets employing Lepidium sativum mucilage using $\mathbf{2}^{3}$ Factorial design
}

\author{
A.Bharathi $^{1 \star}$, K.Vijaya Sree ${ }^{1}$ and D.Chandra Sekhar Naik ${ }^{1}$ \\ ${ }^{1}$ KVSR Siddhartha College of Pharmaceutical Sciences, Siddhartha Nagar, \\ Vijayawada, A.P, India
}

\begin{abstract}
To evaluate fast dissolving tablets for Roflumilast employing with novel superdisintegrant using lepidium sativum mucilage by using $2^{3}$ factorial design. The physical, chemical and micromeritic studies were evaluated for the prepared mucilage. To estabish fast dissolving tablets of Roflumilast with lepidium sativum mucilage ie a superdisinitegrant in different ratios by using direct compression method employing $2^{3}$ factorial design. All the fast dissolving tablets were evaluated pre compression and post compression parameters like dissolution efficiency (DE\%) percent of drug dissolved at 5 min (PD5). The Lepidium sativum mucilage was to be found fine,free flowing crystaline powder and excellent swelling nature in water. The FTIR and DSC studies were indicated to no interactions between roflumilast and Lepidium sativum mucilage. All the formulation batches shows good quality with regrad to drug content $(98 \pm 0.092$ to $100 \pm 0.026)$ hardness $(3.4 \pm 0.43$ to $3.6 \pm 0.64)$ friability $(0.21 \pm 0.04$ to $0.88 \pm 0.42)$. The optimized formulation batch shows less disintegrant time $(52 \pm 0.24)$. The $I n-$ Vitro wetting time was less (i.e., 90s) in optimized formulation F2. The water absorption ratio of the formulated tablets was found to be in the range of $(90.3 \pm 0.027)$. The cumulative drug dissolved in the optimized formulation F2 was found to be ( $99 \%$ ) in 5 min. Lepidium sativum mucilage was found to be a super disintegrant which enhanced the dissolution efficiency when combined with Crospovidone, croscarmellose sodium, and hence it could be used in the formulation of fast dissolving tablets to provide immediate release of the contained drug within 5 min.
\end{abstract}

Keywords : Optimization,fast dissolving, superdisintegrant.

A.Bharathi et al /International Journal of PharmTech Research, 2020,13(1): 52-65.

http://dx.doi.org/10.20902/IJPTR.2019.130107 


\section{INTRODUCTION}

Oral routes of drug administration have wide acceptance up to 50- 60\% of the total dosage forms. Fast dissolving tablets (FDT) are solid dosage form containing indicated substances which disintegrate rapidly, usually within few seconds when placed upon tongue requiring additional water to facilitate swallowing. Fast dissolving tablets offer great advantages for the patients having difficulty in swallowing. The elderly constitute a major portion of today's population mainly because of the increased life span of individuals. Physiological and neurological conditions, such as dysphasia, a risk of choking, and hand tremors are leading causes of patient non-compliance in the self-administration of conventional solid oral dosage forms. Fast dissolving tablets overcome this problem and provide the advantages for paediatrics, geriatric, bedridden, disabled patients and also for who may have difficulty in swallowing tablets, capsules, and liquid orals. FDT will rapidly disintegrate in the mouth without the need of water. Fast dissolving tablet formulation provides sufficient strength, quick disintegration/dissolution in the mouth without water, rapid dissolution and absorption of the drug, which will produce the quick onset of action. Pre gastric absorption of fast dissolving tablets can result in improved bioavailability and as a consequence of reduced dose. Various techniques can be used to formulate fast dissolving tablets. Direct compression one of the techniques which require the incorporation of super disintegrant or highly water-soluble excipients into the formulation to achieve fast tablet disintegration. Direct compression does not require the use of water or heat during the formulation procedure and is the ideal method for moisture and heat-liable medication. The aim of the work was to formulate and characterize fast-dissolving tablets of Roflumilast by utilizing optimization methods for rapid dissolution of drug and absorption employing a new super disintegrant i.e., Lepidium sativum mucilage.

The present senario explan deals with an aim of systematic formulation approach for optimization of Roflumuilast fast dissolving tablets employing lepidium sativum mucilage, sodium starch glycolate, croscarmellose sodium as super disintegrants. A $2^{3}$ factorial design was applied to investigation the main and interaction effects of the three formulation variables i.e., Lepidium sativum mucilage(A),Crospovidone(B), croscarmellose sodium $(\mathrm{C})$, in each case to find the formula with less disintegration time and more dissolution efficiency $5 \mathrm{~min}$.

\section{MATERIALS AND METHODS}

\section{Materials:}

Sodium hydroxide, mannitol was purchased from Finar chemicals Ltd, Ahmedabad., Roflumuilast, crospovidone, croscarmellose sodium was obtained from Yarrow chem. Products, Mumbai. Microcrystalline cellulose was bought from Qualigens fine chemicals, Mumbai. Talc and magnesium stearate was obtained from Molychem, Mumbai.

\section{Isolation of Lepidium sativum mucilage(a novel disintegrant):}

The seeds (100 g) were soaked for 12 hour in distilled water (1litre). Then mucilage was separated by passing through vacuum pump. After that remaining particulate matter separated by passing through muslin cloth. Then separated clear material was treated with acetone. So as to get precipitated mucilage. Drying was done at $45^{\circ} \mathrm{C}$ for $6 \mathrm{~h}$. Then powder was passed through 80 \# mesh sieve and weighed to calculate the yield.

\section{Characterization of Lepidium sativum mucilage:}

The lepidium sativum mucilage prepared was evaluated for the following

\section{Solubility:}

The solubility of lepidium sativum mucilagewas tested in water, aqueous buffer of $\mathrm{pH} 1,2,3,4,5,6,7.4$ and organic solvents like alcohol, acetone, dichloromethane, chloroform, and petroleum ether.

\section{pH:}

The $\mathrm{pH}$ of $3 \% \mathrm{w} / \mathrm{v}$ slurry was measured by $\mathrm{pH}$ meter. 


\section{Melting point:}

The melting point was determined by using melting point apparatus.

\section{Viscosity:}

The viscosity of $1 \%$ dispersion in water was measured using ostwald viscometer.

\section{Swelling index:}

Lepidium sativum mucilage $(200 \mathrm{mg}$ ) was added to $10 \mathrm{ml}$ of water and light liquid paraffin, taken in two different graduated test tubes and mixed. In the tubes the dispersion was allowed to stand for $12 \mathrm{~h}$. The volumes of the sediment in the tubes were noted. The swelling index of the material was determined as follows.

$$
S I \%=\underline{\text { volume of sediment in water }- \text { volume of sediment in light liquid paraffine }} \times 100
$$

\section{Test for gelling property:}

The gelling property (gelatinization) of the starch and lepidium sativum mucilageprepared was evaluated by heating $7 \% \mathrm{w} / \mathrm{v}$ dispersion of each, in water at $1000 \mathrm{C}$ for $30 \mathrm{~min}$.

\section{Particle size:}

The particle size analysis was performed by sieving using standard sieves.

\section{Density:}

The density $(\mathrm{g} / \mathrm{cc})$ was measured by liquid displacement process using benzene as liquid.

\section{Bulk density:}

Both loose bulk density (LBD) and tapped bulk density (TBD) were calculated by transferring the accurate weighed amount of sample in $50 \mathrm{ml}$ measuring cylinder, the granules without any agglomerates and determined the volume of packing and tapped 50 times on a plane surface and tapped volume of packing recorded LBD and TBD measured by following formula 8 .

$$
\begin{gathered}
\text { LBD }=\frac{\text { Mass of powder }}{\text { Volume of packing }} \\
T B D=\frac{\text { Mass of powder }}{\text { Tapped volume of packing }}
\end{gathered}
$$

\section{Percentage compressibility index}

Percentage compressibility of powder mix was determined by Carr's compressibility index calculated by the following formula 9 .

$$
\% \text { Carr's Index }=\frac{\text { TBD-LBD } \times 100}{\text { TBD }}
$$

Where, $\mathrm{TBD}=$ Tapped bulk density; $\mathrm{LBD}=$ Loose bulk density.

\section{Angle of repose}

The frictional forces in loose powder or granules can be determined by the angle of repose. This is the highest angle possible between the surface of a mass of powder or granules and the horizontal plane. Angle of repose is measured by applying the next equation; 


\section{Fourier transform infrared (FTIR) spectroscopy:}

FTIR spectra of lepidium sativum mucilage was recorded on samples prepared in potassium bromide (KBr) disks using a BRUKER FT -IR,(Tokyo, Japan). The preparation of samples was performed in $(\mathrm{KBr})$ disks by means of a hydrostatic press at 6-8 tons pressure. The scanning range was 500 to $4000 \mathrm{~cm}-1$.

\section{X - Ray diffraction:}

Diffraction pattern of Lepidium sativum mucilage was recorded with an X-ray diffractometer (Analytical spectra's Pvt. Ltd., Singapore). X-ray diffraction was performed at room temperature (300C) with a diffractometer; target, $\mathrm{Cu}(\lambda 1.54 \mathrm{~A})$, filter, $\mathrm{Ni}$; voltage, $40 \mathrm{kV}$; current $30 \mathrm{~mA}$; time constant $10 \mathrm{~mm} / \mathrm{s}$; scanning rate 20/min; measured from 2.5-500 at full scale 200.

\section{Drug - Excipients compatibility studies:}

The compatibility of Lepidium sativum mucilagewith the selected drug (Roflumuilast) was evaluated in DSC and FTIR studies.

\section{Differential Scanning Calorimetry (DSC):}

DSC thermograms of Roflumuilast, and their mixtures (1:1) with lepidium sativum mucilage were recorded on Perkin Elmer thermal analyser samples $(2-5 \mathrm{mg}$ ) were sealed into aluminium pans and scanned at a heating rate of $100 \mathrm{C}$ min- 1 over a temperature range $30-3500 \mathrm{C}$.

\section{Preparation of Roflumuilast fast dissolving tablets}

The tablets were prepared by direct compression method employing $2^{3}$ factorial design in which 3 independent variables \{superdisintegrants i.e., Lepidium sativum mucilage(A), crospovidone (B), croscarmellose sodium (C) \} and 1 dependent variable (dissolution efficiency in $5 \mathrm{~min}$ ) were selected. The composition of different formulation of Roflumuilast fast dissolving tablets is given in table no 1, in which superdisintegrants were selected at 2 levels i.e., higher and lower. At the higher level i.e., 5\% concentration of Lepidium sativum mucilage(A), crospovidone (B) and croscarmellose sodium(C) and at the lower level i.e., $0 \%$ concentration of lepidium sativum mucilage(A), crospovidone (B) and croscarmellose sodium(C). For uniformity in particle size each ingredient was flown through \#100 mesh sized screen before mixing. Lepidium sativum mucilage, crospovidone, croscarmellose sodium, mannitol and microcrystalline cellulose were accurately weighed mixed using mortar and pestle, and then Roflumuilast was added. Finally talc and magnesium stearate were administered to the powder mixture. Finally, the mixed blend was compressed by using eight station rotator press Karnawathi Machineries Pvt, Ltd., Ahmedabad, India).

Table No:1 Formulae of Roflumuilast fast dissolving tablets:

\begin{tabular}{lcccccccc}
\hline Ingredints/mg & F1 & F2 & F3 & F4 & F5 & F6 & F7 & F8 \\
\hline Roflumilast & 50 & 50 & 50 & 50 & 50 & 50 & 50 & 50 \\
LS & --- & 12.5 & --- & 12.5 & -- & 12.5 & -- & 12.5 \\
CP & --- & -- & 12.5 & 12.5 & -- & -- & 12.5 & 12.5 \\
CCS & --- & -- & -- & -- & 12.5 & 12.5 & 12.5 & 12.5 \\
Manitol & 30 & 17.5 & 17.5 & 5 & 17.5 & 5 & 5 & -- \\
MCC & 160 & 160 & 160 & 160 & 160 & 160 & 160 & 152.5 \\
Talc & 5 & 5 & 5 & 5 & 5 & 5 & 5 & 5 \\
Mg sterate & 5 & 5 & 5 & 5 & 5 & 5 & 5 & 5 \\
\hline Total & $\mathbf{2 5 0}$ & $\mathbf{2 5 0}$ & $\mathbf{2 5 0}$ & $\mathbf{2 5 0}$ & $\mathbf{2 5 0}$ & $\mathbf{2 5 0}$ & $\mathbf{2 5 0}$ & $\mathbf{2 5 0}$ \\
\hline
\end{tabular}




\section{Evaluation of Roflumuilast fast dissolving tablets:}

\section{Hardness test}

Hardness demonstrates the ability of a tablet to withstand mechanical shocks while handling. The hardness of the tablet was determined using Monsanto hardness tester and expressed in $\mathrm{kg} / \mathrm{cm}^{2} 10$

\section{Uniformity of weight:}

Weight variation test was done with 20 tablets. The individual tablet weight variation from the average weight of 20 tablets.

\section{Friability:}

The friability of tablets was measured using a Roche fribilator. At $25 \mathrm{rpm}$ tablets were rotated for 4 minutes or up to 100 revolutions. Then the tablets were reweighed after removal of fines and the percentage of weight loss was calculated.

\section{Drug content uniformity:}

For content uniformity, ten tablets were weighed and powdered a quantity of powder equivalent to $10 \mathrm{mg}$ of Roflumuilast, which was extracted into 6.8 phosphate buffer and filtered. The Roflumuilast content was calculated by measuring the absorbance spectrophotometrically at $-248 \mathrm{~nm}$ after appropriate dilution with 6.8 phosphate buffer. The drug content was measured as an average of three determinations 11 .

\section{Wetting Time:}

The wetting time of tablets was measured using a very simple procedure five circular tissue papers of 10 $\mathrm{cm}$ diameter were placed in a petridish with a $10 \mathrm{~cm}$ diameter. Ten $\mathrm{ml}$ of water containing a water soluble dye (amaranth) was added to the petridish. A tablet was carefully placed on the tissue paper. Time needed for water to reach the upper surface of the tablet was noted as wetting time.

\section{Water absorption ratio:}

A piece of tissue paper folded twice in a small petridish containing $6 \mathrm{ml}$ of water. A tablet was kept on the tissue paper and allowed to wet completely. The wetted tablet was then weighed. Water absorption ration $\mathrm{R}$ was determined using following equation.

$$
\mathrm{R}=\frac{100\left(\mathrm{~W}_{\underline{\mathrm{d}}}-\mathrm{We}\right)}{\mathrm{We}}
$$

$\mathrm{Wd}=$ weight of tablet after water absorption.

$\mathrm{We}=$ weight of tablet before water absorption.

\section{In - vitro disintegration time:}

Disintegration time for FDTs was determined using USP disintegration apparatus $0.1 \mathrm{~N} \mathrm{HCl}$ buffer. The volume of medium was $900 \mathrm{ml}$ and temperature was $37 \pm 0.20 \mathrm{C}$. The time in second taken for complete disintegration of the tablet with no palatable mass remaining in the apparatus was determined 14.

\section{In - vitro dissolution studies:}

The in- vitro dissolution rate study of Roflumuilast fast dissolving tablets were performed using 8 stage dissolution test apparatus (Lab india -234) fitted with paddles $(50 \mathrm{rpm})$ at $37 \pm 0.50 \mathrm{C}$, using 6.8 phosphate buffer $(900 \mathrm{ml})$ as a dissolution media. At the predetermined time intervals, $5 \mathrm{ml}$ samples were withdrawn, filtered through $0.45 \mu$ membrane filter, diluted and assayed at $-248 \mathrm{~nm}$ using a Analytical technology Elico-SL 218 UV/Visible Double beam spectrophotometer. Cumulative percentage release was measured using standard absorbance from the calibration curve. All the dissolution experiments were conducted in triplicate $(\mathrm{n}=3)$. 


\section{RESULTS AND DISCUSSION}

The prepared Lepidium sativum mucilage was found to be fine, free flowing slightly amorphous powder. The physical and micromeritics properties of the Lepidium sativum mucilage are summarized in table 1. It was insoluble in aqueous solvents and insoluble in organic solvents tested (methanol, petroleum ether, dichloromethane, and chloroform) the $\mathrm{pH}$ of $3 \%$ aqueous dispersion.

Lepidium sativum mucilage exhibited good swelling in water. The swelling index was $50 \%$ all micrometric properties resulted good flow and compressibility needed for solid dosage from manufacturing. The density of Lepidium sativum mucilage was found to be $0.514 \mathrm{~g} / \mathrm{cc}$. The angle of repose and compressibility index showed good flow properties of Lepidium sativum mucilage. The FTIR spectrum of potato starch and Lepidium sativum mucilage is shown in fig:1. The presence of peaks absorption at $2908.38 \mathrm{~cm}-1$ and 2927.26 $\mathrm{cm}-1$ characteristic peaks of ester, so from FTIR studies it was concluded that Lepidium sativum mucilage(ester) was formed when starch was allowed to react with formic acid. The X-ray diffraction pattern (fig: 2) of Lepidium sativum mucilage showed no peaks, which indicates that the structure is slightly amorphous. The disappearance of pink colour in the ester test confirmed the presence of ester, i.e., Lepidium sativum mucilage. As the Lepidium sativum mucilage was slightly amorphous powder and it had got all the characteristic of superdisintegrants it was concluded that lepidium sativum mucilage can be used as novel superdisintegrant in the formulation of fast dissolving tablets.

Table :2 physicochemical character of Lepidium sativum mucilage

\begin{tabular}{l|l}
\hline \multicolumn{1}{c}{ Parameters } & \multicolumn{1}{c}{ Observation } \\
\hline Solubility & $\begin{array}{l}\text { Insoluble in all aqueous and organic solvent } \\
\text { tests }\end{array}$ \\
\hline $\mathrm{pH}(1 \% \mathrm{w} / \mathrm{v}$ aqueous dispersion $)$ & 3.72 \\
\hline Melting point & Charged at $300 \mathrm{C}^{\mathbf{o}}$ \\
\hline Viscosity(1\%w/v aqueous dispersion) & $1.04 \mathrm{cps}$ \\
\hline Swelling index & $66.6 \%$ \\
\hline Gelling properties & $\begin{array}{l}\text { No gelling and the swollen particles of } \\
\text { starchglutarate separate from water } \text { where as in } \\
\text { the case of starch, it was gelatinized and } \\
\text { formed gel. }\end{array}$ \\
\hline Moisture absorption & \begin{tabular}{l}
4.1 \\
\hline Partial size
\end{tabular} \\
\hline Density & $152 \mu \mathrm{m}(80 / 120)$ mesh \\
\hline Bluk density & $0.514 \mathrm{~g} / \mathrm{cc}$ \\
\hline Angle of response & $0.562 \mathrm{~g} / \mathrm{cc}$ \\
\hline Compressibility & $13.03 \mathrm{C}^{\mathbf{o}}$ \\
\hline
\end{tabular}




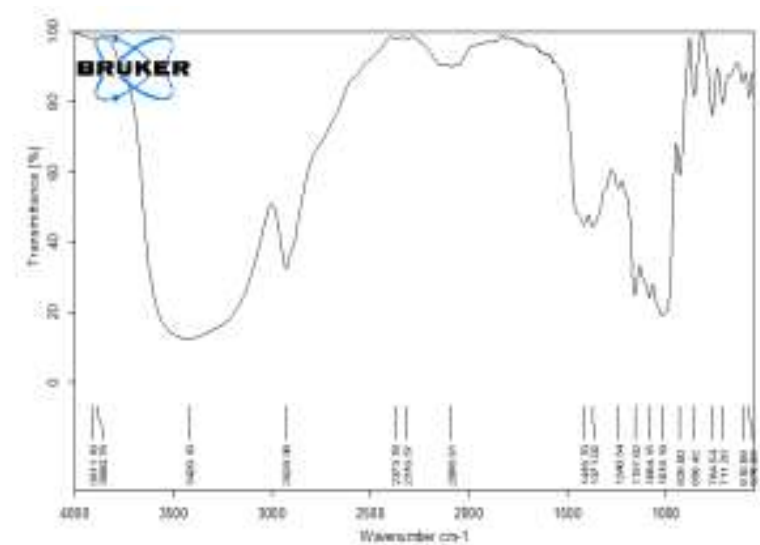

Figure 1: Fourier transform infrared spectra of potato starch.

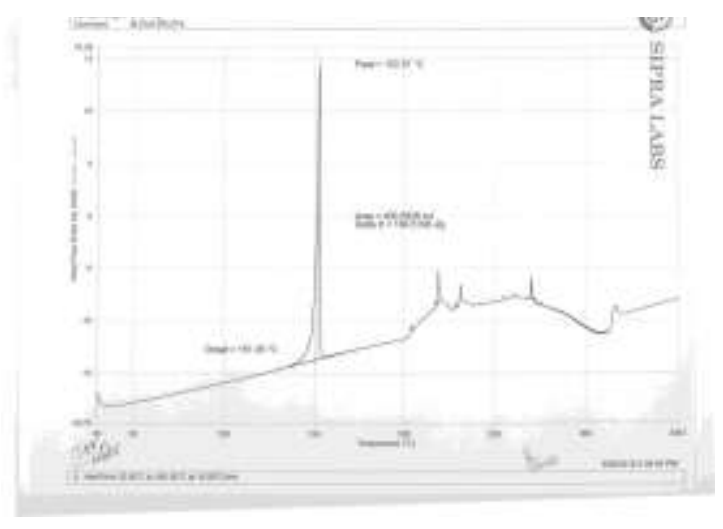

Figure3:DSCThermogram of Roflumuilast pure drug

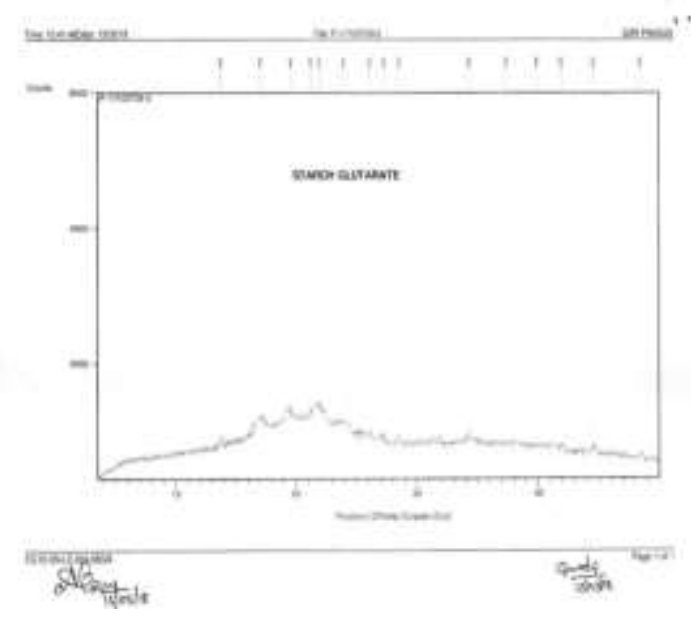

Figure 2: X-Ray diffraction pattern of Lepidium sativum mucilage

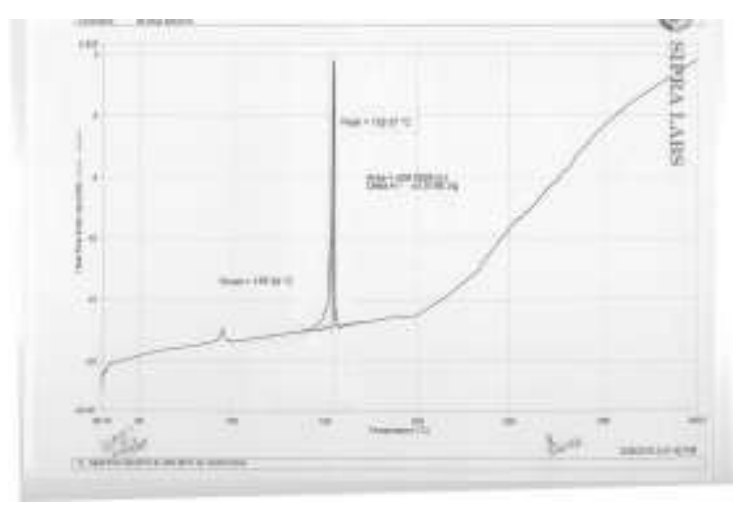

Figure 4: DSC Thermo gram of Roflumuilast with Lepidium sativum mucilage

The X-ray diffraction pattern of Lepidium sativum mucilage showed no characteristic peaks, which indicates that structure is amorphous. The compatibility of Lepidium sativum mucilage with the selected drug (Roflumuilast) was evaluated by DSC, FTIR studies. The DSC thermograms of Roflumuilast and Roflumuilast - Lepidium sativum mucilage are shown in Fig. 3 and 4. The DSC thermograms of Roflumuilast and Roflumuilast- Lepidium sativum mucilage exhibited exothermic peaks at 152.570C and 152.510C respectively. These melting peaks of Roflumuilast and Roflumuilast - lepidium sativum mucilageare nearer to the melting points of Roflumuilast (149-1530C). The peaks observed in the DSC thermograms of Roflumuilast and Roflumuilast - Lepidium sativum mucilage mixtures correspond to the melting points of the respective drug indicating no interactions between the selected drug and lepidium sativum mucilagepolymer. The DSC study, thus, indicated no interaction between Lepidium sativum mucilage and selected drug.

The FTIR spectra of Roflumuilast and Roflumuilast - Lepidium sativum mucilageare characteristic FTIR bands of Roflumuilast at $2968.92 \mathrm{~cm}-1(\mathrm{COOH})$, and Roflumuilast - Lepidium sativum mucilage at $2966.28 \mathrm{~cm}-1(\mathrm{COOH})$ were all observed in the FTIR spectra of both Roflumuilast and Roflumuilast - lepidium sativum mucilage. These FTIR spectra observations also indicated no interaction between Lepidium sativum mucilage and the drug selected.

Thus the result of DSC, FTIR indicated no interaction between the selected drug and Lepidium sativum mucilage, the new superdisintegrant. Hence Lepidium sativum mucilage could be used as a superdisintegrant in the design of fast dissolving tablets of the selected drug. 


\section{Evaluation of tablets}

\section{Hardness}

Hardness of tablets from all batches was found to be in the range of $3.6 \pm 0.03 \mathrm{~kg} / \mathrm{cm} 2$ to $3.9 \pm 0.04 \mathrm{~kg} / \mathrm{cm} 2$. All tablets were found hard enough so that they could easily withstand the handling and storage conditions without getting broken.

\section{Friability}

All the tablets exhibited acceptable friability as none of the tested batches showed percentage friability that exceeded $1 \%$. As per IP, percent friability below $1 \%$ is an indication of good mechanical resistance of the tablets. Percent friability of all batches found in the range of $0.12 \%-0.15 \%$. Thus, it was proved that tablets could withstand the pressure, mechanical shocks during handling, transportation, storage and manufacturing processes.

\section{Drug content}

Drug content of all the formulation batches was found to be between $98.58 \pm 0.81$ to $98.17 \pm 0.61$. Hence, it can be concluded that all the formulations are having an accurate amount of drug distributed uniformly in powder mass and followed acceptable limits as per IP 15. i.e. 85 to $115 \%$ of average content table 3 .

\section{Disintegration studies}

In vitro disintegration time was done by the USP dissolution apparatus. The disintegration rate has a correlation with water absorption capacity of disintegrate and The In vitro disintegration time was found between $30 \pm 0.02$ to $2480 \pm 0.02 \mathrm{~s}$. The outcomes were tabulated and data demonstrated in table 2 . It was found that the formulation F8 will show least disintegration time 30s as compare to other formulation. The order for a disintegration time in fast dissolving tablet was found to be F8 $<\mathrm{F} 2<\mathrm{F} 6<\mathrm{F} 5<\mathrm{F} 4<\mathrm{F} 3<<\mathrm{F} 1$. The order of disintegration time may be due to the interaction and main effects of the super disintegrants used in the fast dissolving tablets.

\section{Water absorption ratio and wetting time}

The water absorption ratio was in between $26 \pm 0.12$ to $100 \pm 0.27$. The wetting time found between $30 \pm 0.17$ $170 \pm 0.02$. The outcomes were tabulated and data demonstrated in table 3 and Fig. 5. It was found that the formulation F8 containing $5 \%$ lepidium sativum mucilage, $5 \%$ crospovidone and $5 \%$ croscarmellose sodium showed less wetting time i.e. $30 \pm 0.17 \mathrm{~s}$ as compared to other formulations.

\section{In vitro dissolution studies}

Dissolution rate depends on the wetting time of the disintegrant, among all the formulations F8 has less wetting time and has greater dissolution rate and then this is the other conformance test for correct selection of desirable. In vitro dissolution studies of all the formulation were done and depicted in fig. 5. In all formulations F8 formulation was selected as the promising formulation containing $5 \%$ stach glutarate, $5 \%$ crospovidone and $5 \%$ croscarmellose sodium with $99.15 \%$ release in 15 min which may be due to the interaction effect between the two super disintegrants i.e., lepidium sativum mucilage, crospovidone and croscarmellose sodium at a concentration of $5 \%$ each. The dissolution parameters of the formulation from (F1-F8) which were made by direct compression method were shown in the table 1 . In all these cases the PD5 (percent dissolved in 5 minute) was more in F8 which consists at $5 \%$ lepidium sativum mucilage, $5 \%$ crospovidone and $5 \%$ croscarmellose sodium. The same was in the case of DE5 \% (dissolution efficiency in $5 \mathrm{~min}$ ). The PD5 \& DE5 \% revels that lepidium sativum mucilagewas effective at $5 \%$, crospovidone at $5 \%$ along with $5 \%$ croscarmellose sodium when the formulations were made by direct compression using these superdisintegrants. To evaluate the individual and combined effects of the three factors involved, fast dissolving tablets were formulated employing selected combinations of the factors as per $2^{3}$ - factorial design. The fast dissolving tablets and release parameters (percent drug released in $5 \mathrm{~min}$ ) of the fast dissolving formulated were analyzed as per ANOVA of $2^{3}$ - factorial design. ANOVA of percentage dissolved in $5 \mathrm{~min}$ (table 5), ANOVA of water absorption ratio (table 4), indicated that the individual effects of Lepidium sativum mucilage(A), crospovidone (B), 
crosscarmellose sodium (C) as well as the combined effects of $\mathrm{AB}, \mathrm{AC}, \mathrm{BC}$ and $\mathrm{ABC}$ factors, were significant $(\mathrm{P}<0.05)$ on percentage dissolved in $5 \mathrm{~min}$, wetting time, water absorption ratio and dissolution efficiency in 5 min of Roflumuilast fast dissolving tablets.

Fast dissolving tablets formulated employing Lepidium sativum mucilage(5\%), crospovidone (5\%) and croscarmellose sodium (5\%) as super disintegrants exhibited in percentage dissolved in $5 \mathrm{~min}$, wetting time, water absorption ratio and dissolution efficiency in $5 \mathrm{~min}$. Formulation F8 gave release of $99.15 \%$ in $15 \mathrm{~min}$ fulfilling the official specification, based on percentage dissolved in 5 min, wetting time, water absorption ratio and dissolution efficiency in 5 min. Formulation F8 is considered as a good fast dissolving tablet formulations.

Table 3: Physical Properties: Hardness, Friability Drug Content of Roflumuilast fast dissolving tablets prepared by direct compression method.

\begin{tabular}{|c|l|l|l|c|c|c|}
\hline $\begin{array}{l}\text { Formulation } \\
\text { code }\end{array}$ & $\begin{array}{l}\text { Hardness } \\
\text { (kg/cm2) }\end{array}$ & $\begin{array}{l}\text { \% } \\
\text { Friability }\end{array}$ & $\begin{array}{l}\text { Disintegration } \\
\text { time(sec) } \\
\text { mean }\end{array}$ & $\begin{array}{l}\text { Wetting } \\
\text { time } \\
\text { (Sec) mean }\end{array}$ & $\begin{array}{l}\text { Water } \\
\text { Absorption } \\
\text { ratio (\%) }\end{array}$ & $\begin{array}{l}\text { Uniformity of } \\
\text { content } \\
\text { mean(\%) }\end{array}$ \\
\hline F1 & $3.5 \pm 0.02$ & $0.21 \pm 0.04$ & $210 \pm 0.21$ & $247 \pm 0.51$ & $30.5 \pm 0.072$ & $99 \pm 0.034$ \\
\hline F2 & $3.6 \pm 0.64$ & $0.67 \pm 0.27$ & $52 \pm 0.24$ & $53 \pm 0.67$ & $90.3 \pm 0.027$ & $98 \pm 0.024$ \\
\hline F3 & $3.5 \pm 0.75$ & $0.92 \pm 0.61$ & $57 \pm 0.34$ & $47 \pm 0.46$ & $91.95 \pm 0.046$ & $99 \pm 0.067$ \\
\hline F4 & $3.4 \pm 0.79$ & $0.38 \pm 0.37$ & $50 \pm 0.91$ & $42 \pm 0.57$ & $86.48 \pm 0.042$ & $99 \pm 0.069$ \\
\hline F5 & $3.5 \pm 0.43$ & $0.10 \pm 0.67$ & $59 \pm 0.34$ & $56 \pm 0.67$ & $89.63 \pm 0.027$ & $98 \pm 0.092$ \\
\hline F6 & $3.5 \pm 0.28$ & $0.43 \pm 0.24$ & $40 \pm 0.87$ & $71 \pm 0.37$ & $90 \pm 0.037$ & $99 \pm 0.037$ \\
\hline F7 & $3.6 \pm 0.35$ & $0.88 \pm 0.42$ & $43 \pm .086$ & $44 \pm 0.67$ & $92.5 \pm 0.89$ & $100 \pm 0.026$ \\
\hline F8 & $3.4 \pm 0.43$ & $0.66 \pm 0.67$ & $49 \pm 0.67$ & $37 \pm 0.46$ & $98.54 \pm 0.073$ & $99 \pm 0.047$ \\
\hline
\end{tabular}

At time $=0$ sec At time $=29$ sec
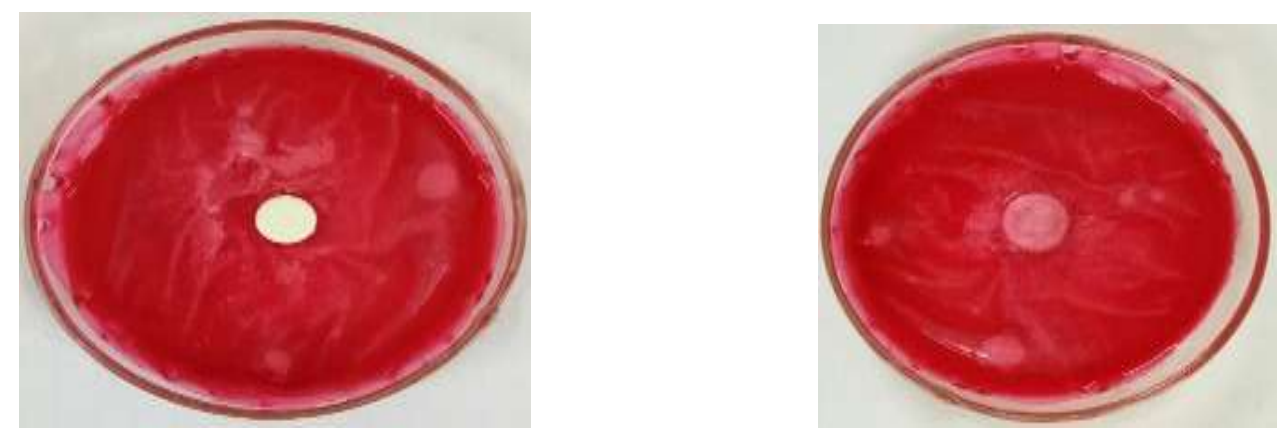

Fig No: 5 Optimized formualtion (F2) of Roflumuilast fast dissolving tablet

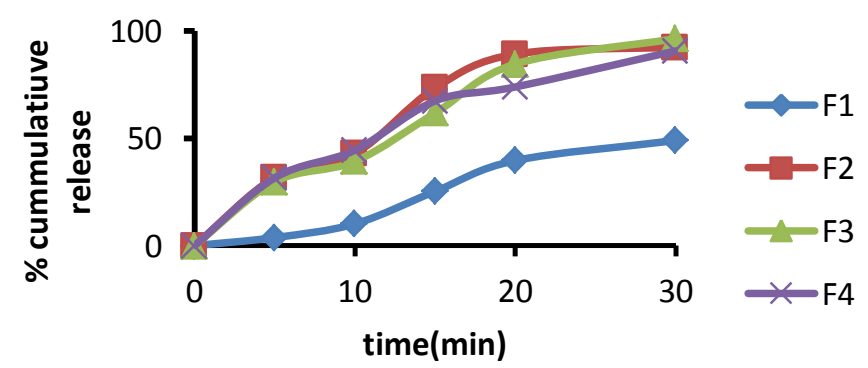

Figure 6: Dissolution profiles of roflumilast fast dissolving tablets prepared employing Lepidium sativum mucilage(F1- F4) 


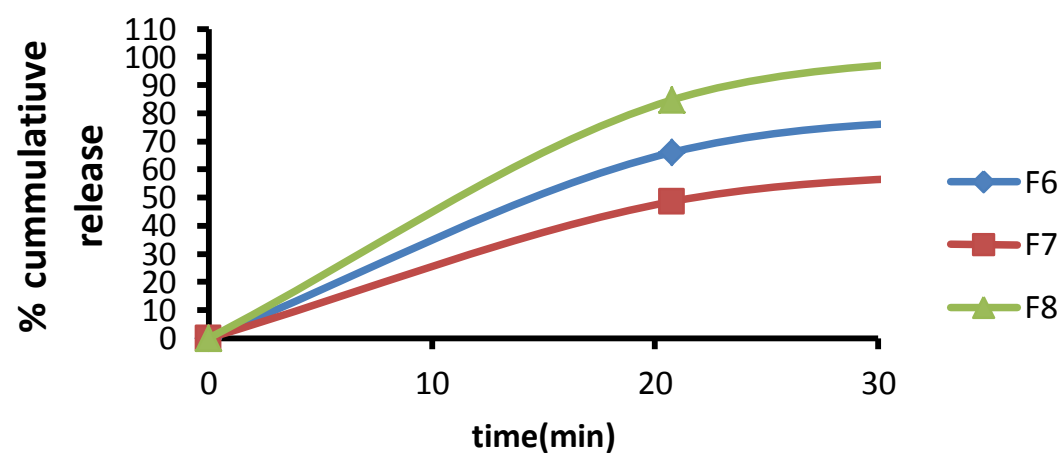

Figure 7 : Dissolution profiles of roflumilast fast dissolving tablets prepared employing Lepidium sativum mucilage(F6- F8)

Table No 4: ANOVA of Drug release at of roflumilast Fast Dissolving Tablets Formulated employing Lepidium sativum mucilage.

\begin{tabular}{|l|l|l|l|c|c|}
\hline Source of Variation & d. f & S.S & M.S.S & $\begin{array}{l}\text { Variance } \\
\text { ratio }\end{array}$ & Result \\
\hline Replicates & 7 & 0.01 & 0.05 & --- & $\mathrm{P}>0.05$ \\
\hline Treatments & 2 & 5539.20 & 791.39 & & $\mathrm{P}<0.05$ \\
\hline Lepidium sativum mucilage(A) & 1 & 1068.39 & 1068.39 & & $\mathrm{P}<0.05$ \\
\hline Crospovidone(B) & 1 & 1923.24 & 1923.24 & & $\mathrm{P}<0.05$ \\
\hline $\begin{array}{l}\text { Lepidium sativum mucilage+ Crospovidone } \\
\text { (AB) }\end{array}$ & 1 & 756.22 & 756.22 & & $\mathrm{P}<0.05$ \\
\hline Croscarmellose sodium (C) & 1 & 85.54 & 85.54 & & $\mathrm{P}<0.05$ \\
\hline $\begin{array}{l}\text { Lepidium sativum mucilage+ } \\
\text { Croscarmellose sodium (AC) }\end{array}$ & 1 & 868.34 & 868.34 & & $\mathrm{P}<0.05$ \\
\hline Crospovidone+ Croscarmellose sodium (BC) & 1 & 1.86 & 1.86 & & $\mathrm{P}<0.05$ \\
\hline $\begin{array}{l}\text { Lepidium sativum mucilage+ Crospovidone+ } \\
\text { Croscarmellose sodium (ABC) }\end{array}$ & 1 & 836.00 & 836.00 & & $\mathrm{P}<0.05$ \\
\hline Error & 0.00 & 0.00 & 0.00 & 0.0000 & -- \\
\hline Total & 7 & 7 & --- & --- & -- \\
\hline
\end{tabular}

*SD Standard Deviation from mean, $\mathrm{n}=3, \mathrm{P}<0.05$ indicate significance; $\mathrm{p}>0.05$ indicate non-significance, $\mathrm{d}$. $\mathrm{f}-$ Degree of Freedom *S. S-Sum of Square *M. S. S-Mean Sum of Squares, ANOVA= Analysis of Variance.

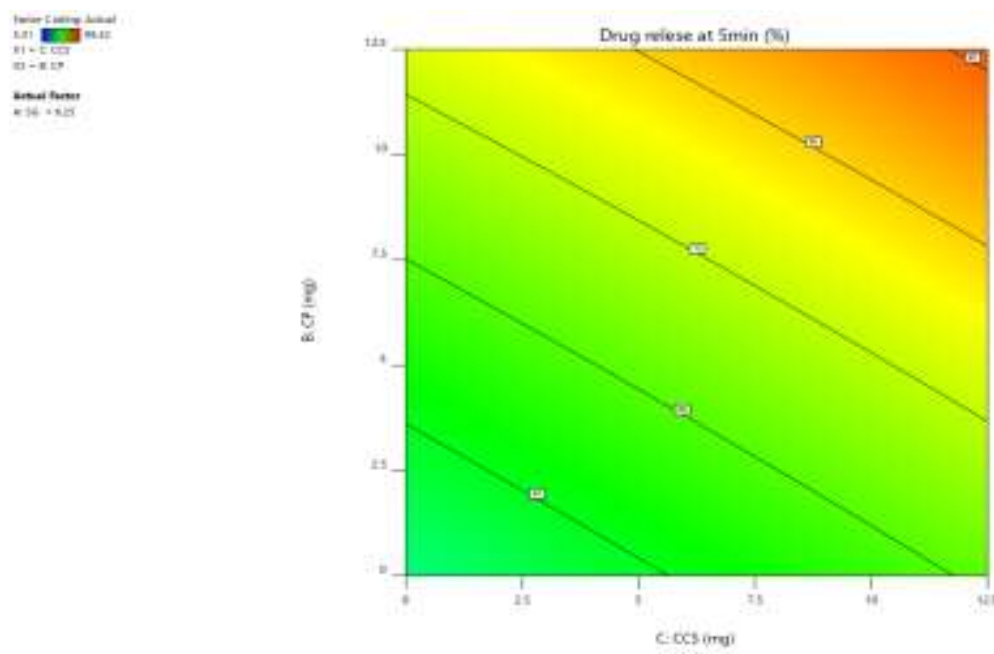

Fig no 8: Countor graph plots for Crospovidone+ Croscarmellose sodium 


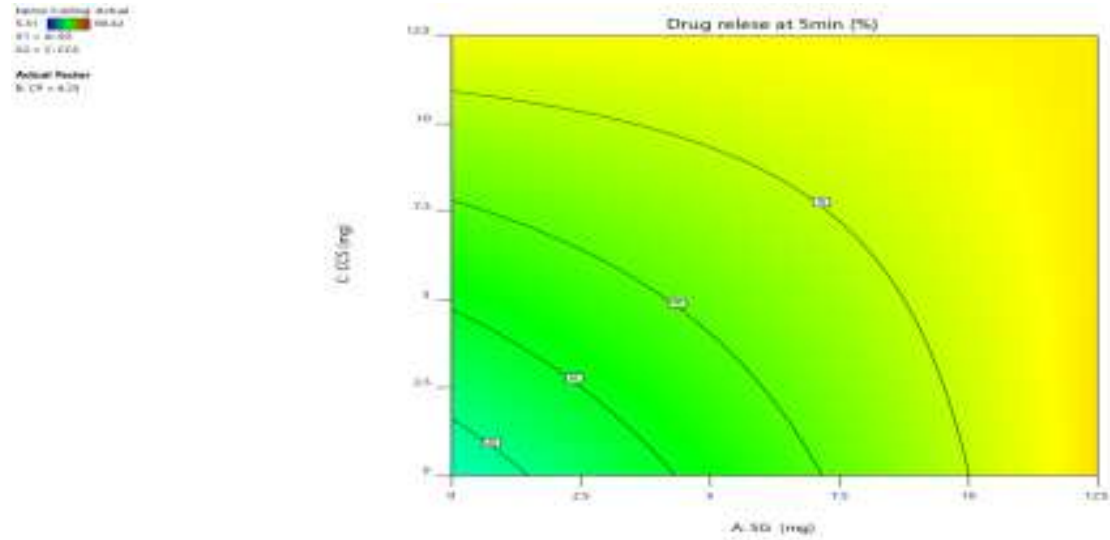

Fig no 9: Countor graph plots for Lepidium sativum mucilage+ Croscarmellose sodium
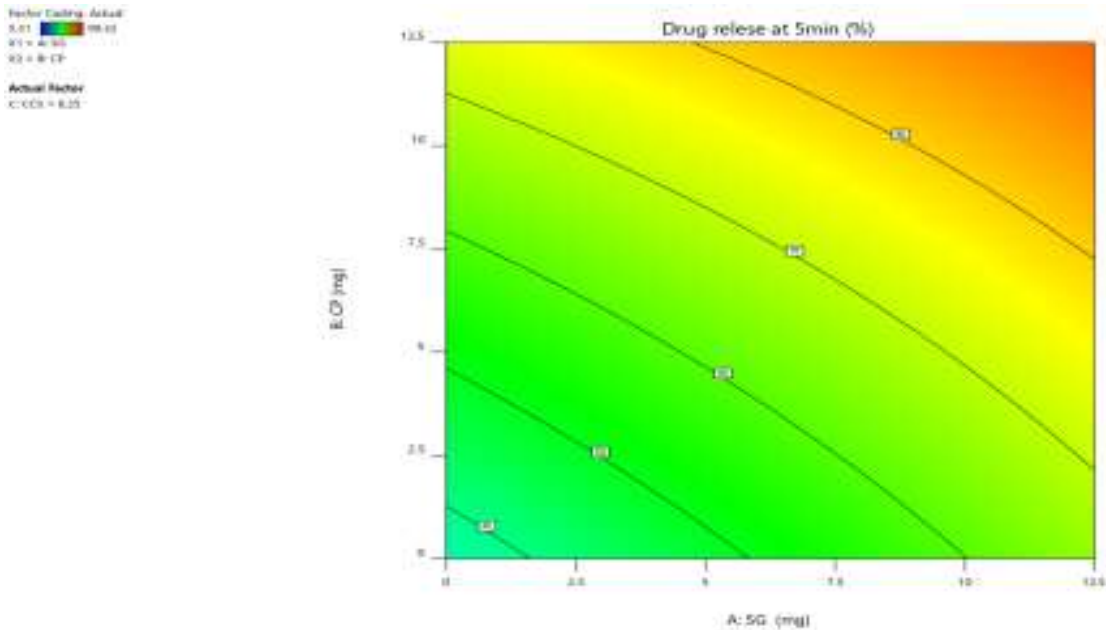

Fig no :10 Countor graph plots for Lepidium sativum mucilage+ Crospovidone

Table no 5: ANOVA of water absorption at of roflumilast Fast Dissolving Tablets Formulated employing Lepidium sativum mucilage.

\begin{tabular}{|l|l|l|l|l|l|}
\hline Source of Variation & d.f & S.S & M.S.S & $\begin{array}{l}\text { Variance } \\
\text { ratio }\end{array}$ & Result \\
\hline Replicates & 7 & 0.01 & 0.05 & --- & $\mathrm{P}>0.05$ \\
\hline Treatments & 2 & 5539.20 & 791.39 & & $\mathrm{P}<0.05$ \\
\hline Lepidium sativum mucilage(A) & 1 & 1068.39 & 1068.39 & & $\mathrm{P}<0.05$ \\
\hline Crospovidone(B) & 1 & 1923.24 & 1923.24 & & $\mathrm{P}<0.05$ \\
\hline $\begin{array}{l}\text { Lepidium sativum mucilage+ Crospovidone } \\
\text { (AB) }\end{array}$ & 1 & 756.22 & 756.22 & & $\mathrm{P}<0.05$ \\
\hline Croscarmellose sodium (C) & 1 & 85.54 & 85.54 & & $\mathrm{P}<0.05$ \\
\hline $\begin{array}{l}\text { Lepidium sativum mucilage+ Croscarmellose } \\
\text { sodium (AC) }\end{array}$ & 1 & 868.34 & 868.34 & & $\mathrm{P}<0.05$ \\
\hline Crospovidone+ Croscarmellose sodium (BC) & 1 & 1.86 & 1.86 & & $\mathrm{P}<0.05$ \\
\hline $\begin{array}{l}\text { Lepidium sativum mucilage+ Crospovidone+ } \\
\text { Croscarmellose sodium (ABC) }\end{array}$ & 1 & 836.00 & 836.00 & & $\mathrm{P}<0.05$ \\
\hline Error & 0.00 & 0.00 & 0.00 & 0.0000 & -- \\
\hline Total & 7 & 7 & --- & -- & -- \\
\hline
\end{tabular}

*SD Standard Deviation from mean, $n=3, P<0.05$ indicate significance; $p>0.05$ indicate non-significance, $d . f-$ Degree of Freedom *S. S-Sum of Square *M. S. S-Mean Sum of Squares, ANOVA= Analysis of Variance. 


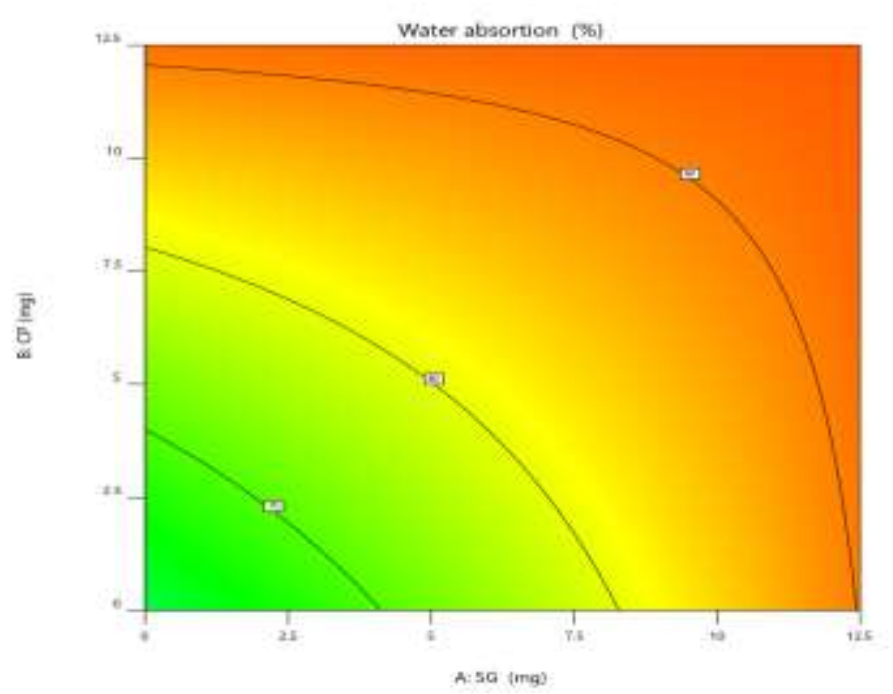

Fig no :11 Countor graph plots for Lepidium sativum mucilage+ Crospovidone
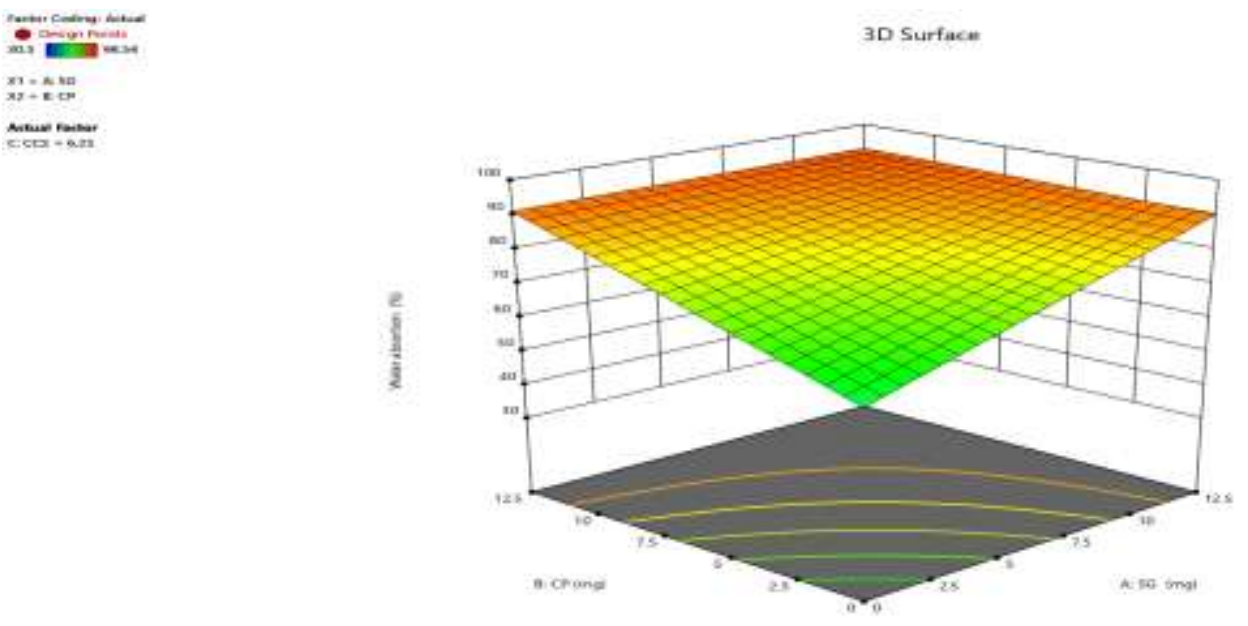

Fig no :12 3D surface graph plots for Lepidium sativum mucilage+ Crospovidone

The response surface plot demonstrated the effect of amount of Lepidium sativum mucilage, Crospovidone, croscarmellose sodium on in vitro drug release. The polynomial equation indicated that drug release was increased $99.05 \%$ at both low and high levels of Lepidium sativum mucilage with increasing concentration of Crospovidone, croscarmellose sodium. The drug release was graduvally increased.

\section{CONCLUSION}

Fast dissolving tablets of Roflumuilast were formulated and optimized using $2^{3}$ factorial design. Three independent variables, that is, amount of $\mathrm{X}_{1}$-amount of Ocimum gratissimum, $\mathrm{X}_{2}$ - Croscarmellose Sodium, $\mathrm{X}_{3}-$ Crospovidone at three levels were selected on the basis of preliminary studies. Addition of superdisintegrant Ocimum gratissimum mucilage leads to significant effect on disintegration characteristics as well as drug release. But higher concentrations of mucilage had negative impact on drug release and disintegration. Addition of Croscarmellose Sodium and Crospovidone leads to improved dissolution characteristics not much affecting 10 ISRN Pharmaceutics disintegration time but higher concentration of Ocimum gratissimum drug disintegration and drug release. The porous nature of tablet with swelling and wicking characteristics of mucilage along with increased drug solubility. The Design-Expert software was used to optimize and response surface plots and contour plots were drawn, and optimum formulations were selected by feasibility and grid searches. Polynomial mathematical models, generated for various response variables using multiple regression 
analysis, were found to be statistically significant $(P<0.05)$. Formulation F2 was selected by the Design-Expert software which exhibited water absorption (97\%), and in vitro drug release (99.34\%) within 10 minutes.

\section{ACKNOWLEDGMENT:}

Authors are very much thankful to the Siddhartha Academy of General \& Technical Education and principal of KVSR Siddhartha College of pharmaceutical sciences for providing facilities.

\section{REFERENCES}

[1] R. Pahwa andN.Gupta, "Superdisintegrants in the development of orally disintegrating tablets: a review," International Journal of Pharmaceutical Sciences and Research, vol. 2, no. 11, pp. 27672780, 2011.

[2] D. Bhowmik, B. Chiranjib, P. Krishnakanth, and R. M. Chandira, "Fast dissolving tablet: an overview," Journal of Chemical and Pharmaceutical Research, vol. 1, no. 1, pp. 163-177, 2009.

[3] P. Sehgal, R.Gupta, S.U. Kumar, C. Ashwani, G. Ashwini, and S. Mansi, "Fast dissolving tablets: a new venture in drug delivery," The American Journal of PharmTech Research, vol. 2, no. 4, pp. 252279, 2012.

[4] M.Mangal and N. Thakur, "Fast dissolving tablets: an approach for emergency treatment," International Research Journal of Pharmacy, vol. 3, pp. 377-380, 2012.

[5] K. Gaur, L. K. Tyagi, M. L. Kori, C. S. Sharma, and R. K. Nema, "Formulation and characterization of fast disintegrating tablet of Aceclofenac by using sublimation method," International Journal of Pharmaceutical Sciences and Drug Research, vol. 3, no. 1, pp. 19-22, 2011.

[6] U. Kulkarni, N. G. Raghavendra, R. C. Hariprasanna, G. Rabbani, and B. S. Patil, "Formulation and development of Aceclofenac fast dissolving tablets-effect of functionality of subliming agents," Journal of Applied Pharmaceutical Science, vol. 2, no. 3, pp. 179-190, 2011.

[7] S. Chakraborty, M. Khandai, S. P. Singh, and N. C. Patra, "Comparative study on effect of natural and synthetic superdisintegrants in the formulation of fast dissolving tablets of Aceclofenac," International Journal of Green Pharmacy, vol. 2, no. 1, pp. 22-25, 2008.

[8] A. H. Vadher, J. R. Parikh, R. H. Parikh, and A. B. Solanki, "Preparation and characterization of cogrinded mixtures of Aceclofenac and neusilin US2 for dissolution enhancement of Aceclofenac," AAPS PharmSciTech, vol. 10, no. 2, pp. 606-614, 2009.

[9] V. Sharma and V. Arora, "Comparison of various natural superdisintegrants in the formulation of fast dissolving carvedilol tablet," International Journal of Pharmaceutical Sciences and Research, vol. 3, no. 10, pp. 3947-3954, 2012.

[10] K. Srinivas, K. Prakash, H. R. Kiran, P. M. Prasad, and M. E. B. Rao, "Study of Ocimum basilicum and Plantago ovata as disintegrants in the formulation of dispersible tablets," Indian Journal of Pharmaceutical Sciences, vol. 65, no. 2, pp. 180-183, 2003.

[11] Y. Bi, "Preparation and evaluation of a compressed tablet rapidly disintegrating in the oral cavity," Chemical and Pharmaceutical Bulletin, vol. 44, no. 11, pp. 2121-2127, 1996.

[12] Y. X. Bi, H. Sunada, Y. Yonezawa, and K. Danjo, "Evaluation of rapidly disintegrating tablets prepared by direct compression method," Chemical and Pharmaceutical Bulletin, vol. 44, pp. 2121-2125, 1996.

[13] M. K. Modasiya, I. I. Lala, B. G. Prajapati, V. M. Patel, andD.A. Shah, "Design and characterization of fast disintegrating tablets of piroxicam," International Journal of PharmTech Research, vol. 1, no. 2, pp. 353-357, 2009.

[14] S. B. Shirsand, S. Suresh, M. S. Para, P. V. Swamy, and D. N. Kumar, "Plantago ovata mucilage in the design of fast disintegrating tablets," Indian Journal of Pharmaceutical Sciences, vol. 71, no. 1, pp. 4145, 2009.

[15] S. B. Shirsand, S. Suresh, and P. V. Swamy, "Formulation design and optimization of fast dissolving clonazepam tablets," Indian Journal of Pharmaceutical Sciences, vol. 71, no. 5, pp. 567-572, 2009.

[16] S. Shailesh and D. G. Ghanshyam, "Development and optimization of fast-dissolving tablets of promethazine theoclate using vacuum drying technology by 3-factor, 3-level response surface full factorial design," Der Pharmacia Lettre, vol. 2, no.6,pp. 124- 135, 2010. 
[17] R. Kumar, S. Patil, M. B. Patil, S. R. Patil, and M. S. Paschapur, "Isolation and evaluation of disintegrant properties of fenugreek seed mucilage," International Journal of PharmTech Research, vol. 1, no. 4, pp. 982-996, 2009. 